\title{
DAMPAK PSIKOLOGI PERNIKAHAN DINI (Studi Kasus di Kecamatan Sanden Bantul Tahun 2014-2017)
}

\author{
Asrofi \\ Program Pasca Sarjana \\ Universitas Muhammadiyah Yogyakarta \\ E-mail: asrofi.faza@gmail.com
}

\begin{abstract}
Abstrak
Penelitian ini mengkaji efek pernikahan dini dari sisi dampaknya terhadap psikologi pelaku. Sehingga tujuan penelitian ini adalah 1) faktor penyebab pernikahan, 2) dampak psikologi dan 3) strategi menanggulangi dampak negatif pernikahan dini di Kecamatan Sanden Kabupaten Bantul tahun 2014-2017. Metode penelitian ini menggunakan deskriptif kualitatif yang dilaksanakan di Kecematan Sanden Kabupaten Bantul tahun 2014-2017. Penelitian ini melibatkan 10 responden pasangan pernikahan dini. Teknik pengumpulan data menggunakan wawancara, observasi dan dokumentasi. Hasil dari penelitian ini adalah 1) penyebab dari pernikahan dini adalah a) karena hamil terlebih dahulu dan b) faktor orang tua. 2) dampak psikologi dari pernikahan dini adalah a) penyesuaian diri menjadi tergangu, b) harmonisasi keluarga, c) tingkat perceraian meningkat, d) hubungan sosial tergangu, d) pola asuh terhadap anak yang tidak kontinu, e) pendidikan yang terhenti dan f) ekonomi yang terpuruk. 3) strategi penanggulangan dampak negatif pernikahan dini adalah a) kerja sama antara keluarga dan penyuluh KUA dengan berkomunikasi secara intens dengan anak, selalu memberikan motivasi serta memberikan tauladan yang positif terhadap anak. b) pemerintah daerah dengan cara memberikan nasehat atau penyuluhan tentang bahaya pergaulan dan reproduksi, pendataan orang-orang yang akan menikah, pengadaan sosialisasi ke desa, sekolah-sekolah dengan menggandeng KUA dan Puskesmas, serta memperketat undang-undang tentang pernikahan.
\end{abstract}

Kata kunci: pernikahan dini, penyebab, dampak psikologis, strategi penanggulangan

\begin{abstract}
This study examines the effects of early marriage in terms of the impact on the psychology of the perpetrator. So the purpose of this study is 1) the factors that cause marriage, 2) the impact of psychology and 3) strategies to overcome the negative effects of early marriage in Sanden District, Bantul Regency in 2014-2017. This research method uses descriptive qualitative carried out in Sanden Sub-district, Bantul Regency in 2014-2017. This study involved 10 respondents to early marriage partners. The technique of collecting data uses interviews, observation and documentation. The results of this study are 1) the causes of early marriage are a) due to pregnancy first and b) parents' factors. 2) the psychological impact of early marriage is a) adjustment to be disturbed, $b$ ) harmonization of the family, $c$ ) divorce rate increases, $d$ ) interrupted social relations, $d$ ) upbringing of children who are not continuous, e) education that is stalled and f) economic downturn. 3) the strategy for overcoming the negative impacts of early marriage is a) cooperation between family and KUA counselors by communicating intensely with children, always providing motivation and giving positive examples to children. $b)$ the regional government by providing advice or counseling on the dangers of association and reproduction, data collection of people who will get married, procuring socialization to the village, schools by cooperating with KUA and Puskesmas, and tightening the law on marriage.

Keywords: early marriage, causes, psychological impact, coping strategies
\end{abstract}

\section{Info Artikel}

Diterima Februari 2019, disetujui Maret 2019, diterbitkan Juni 2019 


\section{PENDAHULUAN}

Agama Islam adalah agama fitrah, dan manusia diciptakan Allah sesuai dengan fitrah. Oleh karena itu, Allah menyeru manusia untuk menghadapkan diri mereka ke agama agar tidak terjadi penyelewengan dan penyimpangan sehingga manusia tetap berjalan di atas fitrahnya. Salah satu seruan Allah yang bersifat fitrah tersebut adalah pernikahan. Pernikahan bagi masyarakat Indonesia merupakan peristiwa yang sakral, oleh karena itu masih tetap menjunjung tinggi nilai adat dan agama yang beraneka ragam. Hal ini semakin dipertegas dengan dikeluarkannya undang-undang tentang perkawinan.

Undang-Undang Nomor 1 Tahun 1974 Pasal 1 menyatakan bahwa pernikahan adalah ikatan lahir batin antara seorang pria dan seorang wanita sebagai suami istri dengan tujuan membentuk keluarga atau rumah tangga yang bahagia dan kekal berdasarkan Ketuhanan Yang Maha Esa. Di antara banyaknya bentuk pernikahan yang terjadi, terdapat fenomena pernikahan dini pada kalangan remaja. Pada hakekatnya pernikahan dini adalah sebuah bentuk ikatan atau pernikahan yang salah satu atau kedua pasangan berusia di bawah 18 tahun atau sedang menempuh pendidikan sekolah dan masih termasuk dalam kategori usia remaja. Jadi sebuah pernikahan disebut pernikahan dini, jika kedua atau salah satu pasangan masih berusia di bawah 18 tahun yakni masih berusia remaja.

Menurut Edi Nur Hasmi, menikah dalam usia muda, memiliki dua dampak cukup berat yaitu, pertama dari segi fisik. Hal ini karena remaja itu belum kuat, tulang panggulnya masih terlalu kecil sehingga bisa membahayakan dalam proses persalinan. Sehingga bisa berakibat fatal bagi ibu yang melahirkan maupun anaknya. Oleh karena itu pemerintah mendorong perempuan jika ingin hamil sebaiknya pada usia 20-30 tahun.

Kedua, dari segi mental. Jika remaja menikah di usia yang masih muda, maka sesungguhnya emosi mereka belum stabil (BKKBN, 2002). Kestabilan emosi umumnya terjadi pada usia di atas 20 tahun, karena pada saat itulah orang mulai memasuki usia dewasa. Masa remaja, boleh di bilang baru berhenti pada usia 19 tahun dan sedangkan ketika seseoraang menikah pada usia 20-24 tahun, secara usia bisa disebut dewasa muda atau lead edolesen. Pada masa ini, biasanya mulai timbul transisi dari gejolak remaja ke masa dewasa yang lebih stabil. 
Di kecamatan Sanden Kabupaten Bantul terdapat sejumlah kasus pernikahan dini. Menurut Undang-undang Pernikahan Nomor 1 Tahun 1974, menyatakan usia ideal untuk menikah yaitu di usia 21 tahun, sedangkan pernikahan yang terjadi pada usia 16 tahun untuk anak perempuan dan 19 tahun untuk laki-laki. Sehingga ketika akan melaksanan pernikahan pasangan calon pengantin tersebut diharuskan memiliki surat ijin atau rekomendasi dari Pengadilan Agama Kabupaten Bantul.

\section{PERNIKAHAN DINI}

Nikah secara bahasa adalah berkumpul dan bergabung. Nikah secara istilah adalah akad yang dilakukan antara laki-laki dan perempuan yang dengannya dihalalkan baginya untuk melakukan hubungan seksual.Undang-undang Pernikahan Nomor 1 Tahun 1974, menyatakan usia ideal untuk menikah yaitu diusia 21 tahun, sedangkan pernikahan yang terjadi pada usia 16 tahun untuk anak perempuan dan 19 tahun untuk laki-laki menurut Undang-undang Perlindungan Anak Nomor 23 Tahun 2002, pernikahan tersebut termasuk pada golongan pernikahan dini. Pasal 26 Undang-Undang Republik Indonesia Nomor 23 Tahun 2002 tentang Perlindungan Anak, orang tua diwajibkan melindungi anak dari pernikahan dini, tetapi pasal ini sebagaimana Undangundang Pernikahan, tanpa ketentuan sanksi pidana sehingga ketentuan tersebut nyaris tak ada artinya dalam melindungi anak-anak dari ancaman pernikahan dini.

Dari segi psikologi sosial maupun hukum Islam pernikahan dini dibagi menjadi dua kategori, pertama pernikahan dibawah umur asli yaitu pernikahan dini yang benarbenar murni dilaksanakan oleh kedua belah pihak untuk menghindarkan diri dari dosa tanpa adanya maksud semata-mata hanya untuk menutupi perbuatan zina yang telah dilakukan oleh kedua mempelai. Kedua, pernikahan dini palsu yaitu pernikahan dini yang pada hakikatnya dilakukan sebagai menutupi kesalahan-kesalahan mereka dalam hal ini orang tua juga ikut berpera serta.

Namun jika dilihat dari segi psikologis usia remaja belum bisa dikatakan matang, karena pada usia remaja belum mempunyai kepribadian yang mantap dan masih labil, dan pada usia remaja pada umumnya belum mempunyai pegangan dalam hal sosial dan ekonomi. Remaja masih canggung dalam hidup berbaur dengan masyarakat luar, dan mereka belum mempunyai pekerjaan yang tetap dan kadang masih bergantung pada 
orang lain. Hal ini akan membuat runyam sebuah rumah tangga, sehingga akan menjadi bibit-bibit pertengkaran yang berakhir dengan perceraian.

Ada beberapa faktor terjadinya pernikahan dini, yaitu: faktor pendidikan, faktor ekonomi, karena kebiasaan dan adat istiadat setempat, melanggengkan hubungan dan faktor telah melakukan hubungan biologis (married by exident). Pernikahan dini memberikan banyak problematika baik bagi pelaku maupun orang-orang yang ada di sekitarnya. Dampak negatif dari pernikahan dini diantaranya adalah pendidikan, kependudukan dan kelangsungan rumah tangga. Menurut Walgito, perkawinan yang masih terlalu muda banyak mengundang masalah yang tidak diharapkan karena segi psikologisnya belum matang seperti cemas dan stress. Sedangkan menurut Dariyo pernikahan bisa berdampak cemas, stress dan depresi.

\section{METODE PENELITIAN}

Dalam hal ini peneliti menggunakan jenis penelitian deskriptif kualitatif. Penelitian kualitatif merupakan penelitian yang bermaksud untuk memahami fenomena tentang apa yang dialami oleh subyek penelitian misalnya perilaku, persepsi, motivasi, tindakan, dan lain-lain, secara holistik, dan dengan cara deskripsi dalam bentuk katakata dan bahasa, pada suatu konteks khusus yang alamiah dan dengan memanfaatkan berbagai metode alamiah.

Tempat penelitian atau lokasi penelitian dilaksanakan di masyarakat Kecamatan Sanden Kabupaten Bantul dengan masa pernikahan tahun 2014-2017. Subjek dalam penelitian ini sebanyak 10 keluarga dari pernikahan dini dalam kurun masa pernikahan antara tahun 2014-2017. Metode pengumpulan data dalam penelitian ini menggunakan observasi, wawancara dan dokumentasi. Teknik analisis data menggunakan reduksi, display dan verifikasi data atau kesimpulan. 


\section{HASIL PENELITIAN DAN PEMBAHASAN}

\section{Faktor Penyebab Pernikahan Dini}

Setelah melakukan kajian yang mendalam, berikut adalah penyebab pernikahan dini yang terjadi di Kecamatan Sanden, yaitu:

a. Nikah karena Hamil (Married By Accident)

Kehamilan terjadi akibat melakukan hubungan seks sebelum menikah dengan pacarnya, karena permintaan pacar dan rangsangan dari tontonan pornografi. Mereka melakukan hubungan tersebut di rumah ketika sepi. Remaja melakukan hubungan seksual sebelum menikah salah satunya karena paparan pornografi. Dengan demikian, jika remaja cenderung senang terhadap pornografi akan timbul rangsangan-rangsangan yang mengarah pada seks. Rangsangan ini mendorong remaja untuk melakukan hubungan seks pranikah yang pada akhirnya memberikan dampak kehamilan di luar perkawinan.Berdasarkan keterangan dari KUA Sanden bahwa penyebab pernikahan dini adalah pergaulan bebas dan ekonomi.

"Pernikahan dini di Sanden kebanyakan penyebabnya adalah hamil terlebih dahulu. Dari tahun 2014-2017 sekitar 90\% karena hamil dan hanya 1 orang saja yang disebabkan karena faktor ekonomi”.

Berdasarkan wawancara peneliti sebanyak $90 \%$ penyebab pernikahan dini di Kecamatan Sanden adalah hamil (married by accident). Sedangkan $10 \%$ atau 1 keluarga menikah karena faktor ekonomi. Hal ini menunjukan perlunya pendampingan yang ekstra terhadap pergaulan anak muda di era modern.

Tabel 1.

Pernikahan Dini Kecamatan Sanden Tahun 2014-2017




b. Kondisi Orang Tua

Anak-anak akan mencontoh perilaku orang tuanya. Oleh karena itu dalam membentuk karakter anak orang tua hendaknya dapat memahami tahapan-tahapan pendidikan karakter. Maka jika disadari orang tua yang ideal akan mempengaruhi pembentukan karakter dari anak-anaknya. Akan tetapi sulitlah kiranya untuk menyebut orang tua ideal itu karena derasnya pengaruh sosial budaya. Sosial budaya dipengaruhi oleh modernitas. Di era dahulu sosial budaya kita membentuk masyarakat bersahaja, di masa sekarang membentuk masyarakat madya, dan tentu saja di era yang akan datang akan membentuk masyarakat modern yang kesemuanya mempengaruhi kepribadian masing-masing.Ada beberapa alasan orang tua menikahkan anaknya di usia yang yang belum matang (dini), yaitu:

1) Ekonomi Orang tua

Dari faktor orang tua sangat berperan dalam pernikahan dini anak. Keluarga dari kalangan status ekonomi bawah dengan mayoritas orangtua berpendidikan rendah secara sengaja menikahkan anak perempuannya pada usia muda agar dapat meringankan beban keluarga. Kondisi ekonomi yang sulit dan pola asuh orang tua yang bebas mengakibatkan pergaulan anak menjadi tidak terkontrol. Rata-rata pekerjaan orang tua adalah buruh bangunan atau buruh tani sehingga kondisi rumah juga sangat sederhana.

"Urip nggih kados mekaten pak. Saget dhahar mawon sampun syukur. Harapan kulo lare saget ngangkat derajat tyang sepuh. Nanging kok dados mekaten. Tasih bocah kok sampun gadhah lare" (Hidup kami ya seperti ini pak. Bisa makan setiap hari saja sudah bersyukur. Saya berharap suatu saat nanti, anak kami bisa mengangkat derajat orang tua. Namun ternyata takdir berkata lain. Masih kecil namun sudah memiliki anak).

Diantara mereka ada yang memiliki pekerjaan tetap juga pekerjaan tidak tetap.

Oleh karena itu untuk penghasilan yang mereka peroleh setiap harinya tidak menentu. Bahkan tidak sedikit rumah mereka masih beralas tanah dan dinding rumah masih batu bata yang belum dialuskan (plester dan aci). 
Tabel 2.

Pekerjaan Orang Tua

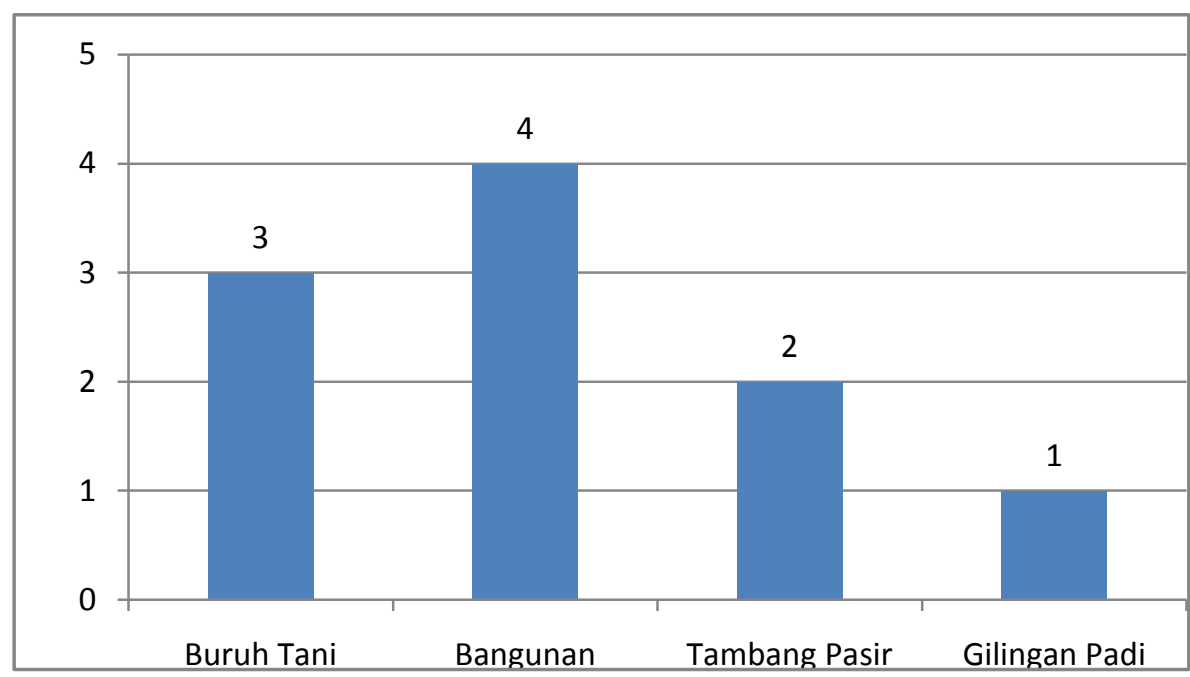

Berdasarkan tabel di atas dapat dijelaskan bahwa sebanyak 3 orang tua yang bekerja sebagai buruh tani, sebanyak 4 orang tua bekerja sebaga buruh bangunan, sebanyak 2 orang bekerja sebagai penambang pasir di kali (sungai) dan 1 orang tua yang usaha gilingan padi keliling. Dengan melihat jenis pekerjaan orang tua dari subjek penelitian di atas, maka tentu berpengaruh dengan penghasilan yang di dapat.

Tabel 3.

Daftar Penghasilan Orang Tua

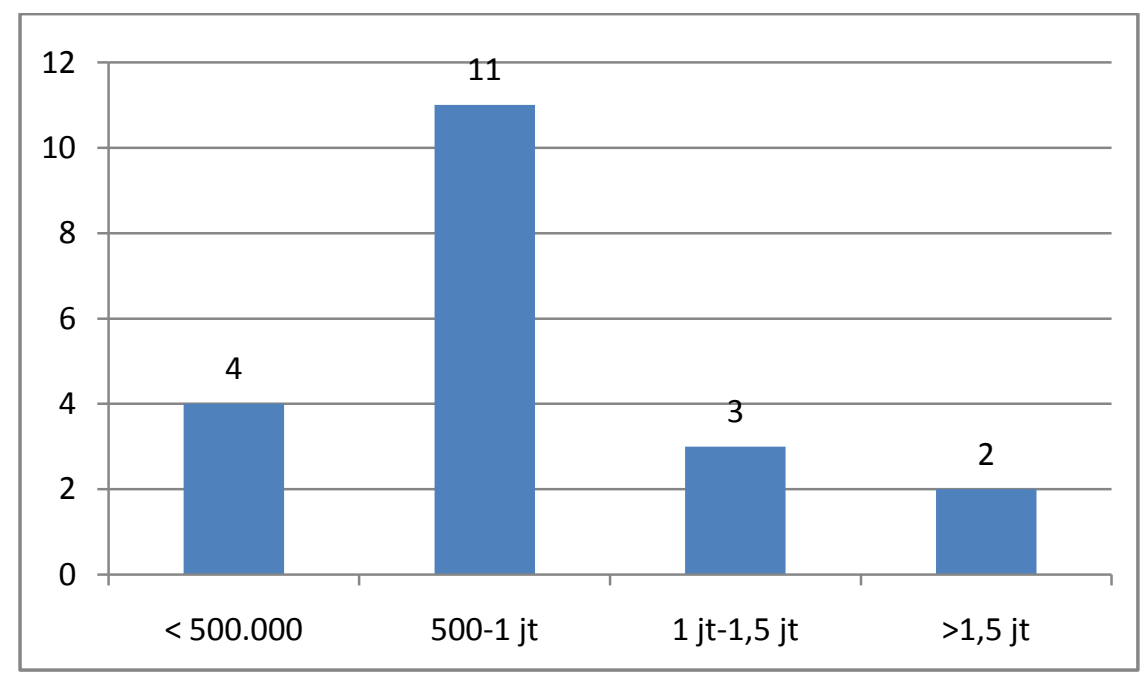

Berdasarkan tabel di atas mayoritas penghasilan dari ke-20 orang tua berkisar antara 500.000 sampai dengan 1.000 .000 sebanyak 11 orang, kisaran penghasilan di bawah 500.000 sebanyak 4 orang, kisaran 1.000.000 sampai 
1.500.000 berkisaran 3 orang dan penghasilam di atas 1.500 .000 sebanyak 2 orang.

2) Pendidikan Orang tua

Di samping perekonomian yang kurang serta pendidikan orang tua yang rendah, akan membuat pola pikir yang sempit. Berikut ini tabel hasil wawancara dengan orang tua tentang pendidikan orang tua yaitu:

Tabel 4.

Pendidikan Orang Tua

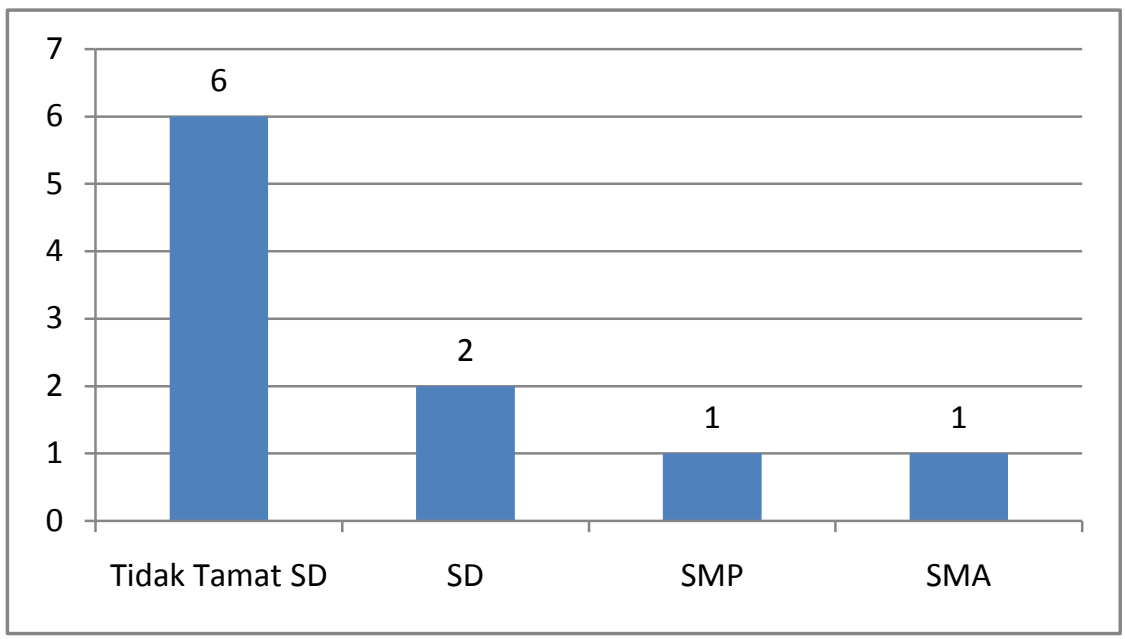

Berdasarkan tabel di atas mengenai pendidikan orang tua yaitu sebanyak 6 orang tidak tamat SD, sebanyak 2 orang tamat SD, sebanyak 1 orang tua taat SMP dan sebanyak 1 orang tamat SMA. Dalam menyikapi masalah dan membuat keputusan termasuk hal yang lebih kompleks atau pun kematangan psikososialnya sangat dipengaruhi oleh tingkat pendidikan. Orang tua yang memiliki latar belakang pendidikan yang tinggi memiliki resiko lebih kecil untuk menikah dini dibandingkan dengan orang tua yang memiliki latar belakang pendidikan rendah.

3) Pola asuh orang tua

Orang tua mempunyai pengaruh yang besar terhadap anak. Sehingga anak merupakan pencitraan dari orang tua. Hal ini menjadi perhatian orang tua untuk mampu menjadi teladan bagi anak-anaknya. Kualitas penghayatan orang tua terhadap pribadi maupun sebagai pengasuh dalam membantu anak memiliki dasar-dasar dan pengembangan disiplin diri. Sehingga dalam perkembangannya, 
anak diharapkan mampu memiliki rasa tanggung jawab dan dasar-dasar disiplin diri.

Tabel 5.

Pola Asuh Orang Tua

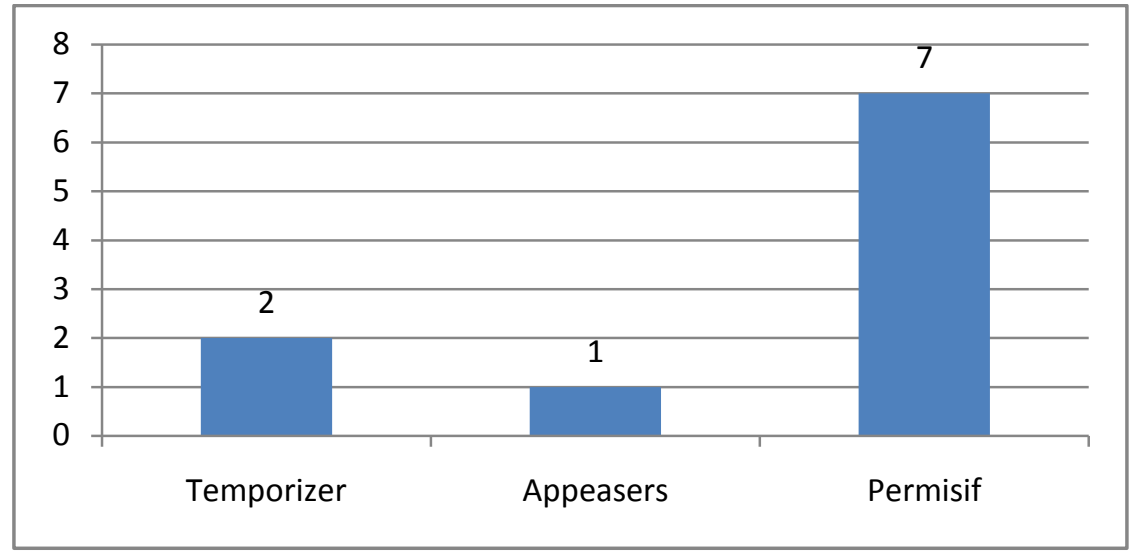

Berdasarkan tabel di atas, sebanyak 2 orang tua menerapkan pola asuh temporizer (pola asuh tidak konsisten artinya dalam mendidik anak orang tua tidak memiliki pendirian), 1 orang tua menerapkan pola asuh appeasers (pola asuh yang khawatir) dan sebanyak 7 orang tua menerapkan pola asuh permisif (memberikan kebebasan pada anak tanpa memberikan kontrol).

4) Tingkat Pemahaman Agama Orang tua

Pemahaman yang lemah terhadap agama juga memberikan pengaruh yang besar terhadap pernikahan dini. Pemahaman yang lemah terhadap agama, mengakibatkan pengawasan terhadap anak juga lemah. Hal ini berakibat pada lemahnya pemantauan orang tua terhadap pergaulan anak. Anak menjadi bebas pergaul dan pergi dengan lawan jenis yang bukan mukhrimnya. Karena tidak adanya kontrol dari orang tua maka anak menjadi leluasa berbuat dan bertindak. Berdasarkan wawancara dengan beberapa orang tua, mereka cenderung kurang perhatian atau cuek dengan pergaulan anak. Alasan mereka jangankan mau mikir pergaulan anak, mikir tentang besuk mau makan apa saja sudah pusing. Bagi orang tua yang penting anak terlihat di rumah dalam kondisi baik-baik saja. 


\section{DAMPAK PSIKOLOGI PERNIKAHAN DINI}

Pernikahan yang terlalu muda juga bisa menyebabkan neuritis depresi karena mengalami proses kekecewaan yang berlarut-larut dan karena ada perasaan-perasaan tertekan yang berlebihan. Kematangan sosial-ekonomi dalam perkawinan sangat diperlukan karena merupakan penyangga dalam memutarkan roda keluarga sebagai akibat perkawinan. Pada umumnya umur yang masih muda belum mepunyai pegangan dalam hal sosial ekonomi. Berdasarkan hasil wawancara dan observasi yang peneliti lakukan, ada beberapa dampak psikologi dari pernikahan dini yang terjadi di masyarakat Kecamatan Sanden, yaitu:

a. Penyesuaian Diri yang Terganggu

Manusia dituntut untuk menyesuaikan diri dengan lingkungan sosial, kejiwaan, dan lingkungan alam sekitarnya. Kehidupan itu sendiri secara alamiah juga mendorong manusia untuk terus-menerus menyesuaikan diri. Penyesuaian diri artinya suatu proses dinamika yang bertujuan untuk mengubah perilaku individu agar terjadi hubungan yang lebih sesuai antara diri individu dengan lingkungannya. Dengan batasan tersebut dapat diberikan batasan bahwa kemampuan manusia sanggup untuk membuat hubungan-hubungan yang menyenangkan antara manusia dengan lingkungaya.Cemas dan depresi akan menghampiri bagi mereka yang menikah di usia dini. Rasa malu dan menyesal terhadap apa yang terjadi, apalagi penyebab pernikahan dini adalah hamil di luar nikah. Perbuatan tersebut akan mejadi aib bagi keluarga besar yang sulit dihilangkan. Berdasarkan wawancara dengan mayoritas subjek mereka mengatakan menyesal menikah di usia muda.

“Aku sangat menyesal. Kenapa dulu melakukannya. Sehingga akhirnya aku hamil. Dulu aku tidak mendengarkan omongan orang tua. Aku merasa depresi dengan kondisi seperti ini. Pernah ada rencana untuk menggugurkan kandungan, namun was-was kalau nanti terjadi dengan saya." 
Tabel 6.

Kondisi Psikologi Pernikahan Dini

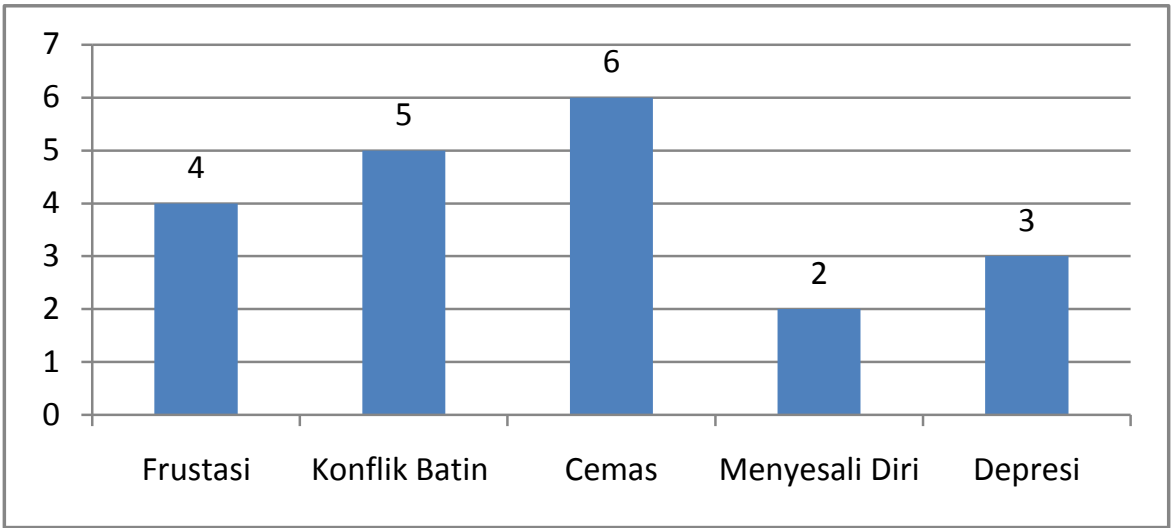

Berdasarkan tabel di atas dapat dijelaskan bahwa hasil wawancara dengan 10 pasangan (20 orang) hasil pernikahan dini adalah sebanyak 4 orang mengalami frustasi, 5 orang mengalami konflik batin, 6 orang mengalami kecemasan, 2 orang menyesali diri dan 3 orang mengalami depresi.

b. Sering Terjadi Pertengkaran

Perkawinan yang masih terlalu muda banyak mengundang masalah yang tidak diharapkan karena segi psikologisnya belum matang seperti cemas dan stress. Berdasarkan hasil penelusuran peneliti telah terjadi perceraian dari subjek pernikahan dini. Perceraian terjadi karena suami pergi dan tidak bertanggung jawab, sesuai dengan hasil interview berikut ini:

"Kami sering bertengkar pak, baik tentang anak, tempat tinggal dan masalah duit. Masih susah ngontrol emosi”.

Tabel 7.

Harmonisasi Keluarga Pernikahan Dini

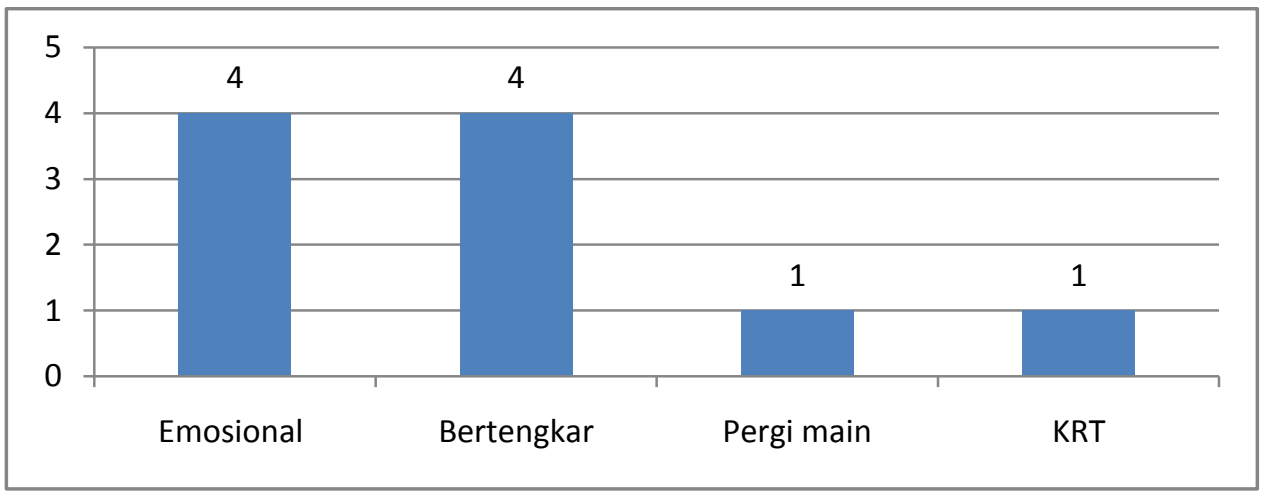


Berdasarkan hasil tabel di atas, dari 10 pasangan pernikahan dini sebanyak 4 orang masih sering emosi yang meluap-luap, sebanyak 4 orang sering terjadi pertengkaran dalam rumah tangga, sebanyak 1 orang masih sering pergi dengan teman-teman dan 1 orang pernah terjadi kekerasan dalam rumah tangga.

c. Perceraian yang Selalu Membayangi

Dalam sebuah rumah tangga sulit digambarkan tidak terjadinya percekcokan. Akan tetapi percekcokan itu sendiri beragam bentuknya; ada yang ibarat seni dan irama dalam kehidupan rumah tangga yang tidak mengurangi keharmonisan dan ada pula yang menjerumuskan kepada kemelut yang berkepanjangan yang dapat terjadi putusnya perkawinan. Diantara sebab-sebab perceraian adalah krisis ekonomi, kesenjangan pikiran dan mental, mengungkap aib rumah tangga, dorongan keluarga kedua belah pihak, perbedaan status sosial dan ketidakharmonisan rumah tangga. Dari kasus pernikahan dini yang terjadi di Kecamatan Sanden dalam kurun 20142017 sudah ada kasus percerian dari pernikahan dini sebanyak 1 orang. Berdasarkan interview alasan perceraian adalah karena suami tidak tanggung jawab.

"saya bercerai dengan suami, karena suami tidak tanggung jawab pak. Lha pripun, suami sering minum-minuman keras, suka mukulin saya dan tidak bekerja. Lalu apa yang tak harapkan dengan laki-laki seperti itu. Alhamdullah setelah bercerai, saya menikah lagi dengan seseorang yang insya Allah baik dan bisa menuntun ke jalan yang diridhoi oleh Allah swt.

d. Hubungan Sosial

Manusia adalah makhluk sosial yang tidak dapat lepas dari manusia yang lain. Dimanapun dan kapanpun dia berada akan selalu tergantung pada orang lain. Untuk itulah manusia selalu berhu-bungan atau berinteraksi dengan manusia lain, baik secara individu, baik secara individu atau secara kelompok. Dalam proses interaksi tersebut tentu ada hubungan dengan yang sifatnya timbal balik.

"Ketika ada acara di kampung seperti kumpulan biasanya diwakili bapak atau mertua. Saya males kalau kumpul dengan bapak-bapak. Kadang juga malu karena yang sudah terjadi. Bahkan kumpulan muda-mudi saja saya sekarang sudah jarang datang, karena malu". 
e. Pola Asuh Anak yang Tidak Jelas

Orang tua sangat berpengaruh besar dalam kehidupan anak diantaranya, pembentukan kepribadian anak, memilih agama yang benar sesuai ajaran al-Qur'an, kelangsungan hidup anak, dan masa depan anak kelak. Orang tua bertanggung jawab pada anak di dunia dan di akhirat kelak. Orang tua adalah guru dan orang terdekat bagi anak yang harus menjadi panutan. Karenanya, orangtua dituntut untuk bekerja keras untuk memberikan contoh dalam memelihara ketaatan serta ketekunan dalam beribadah dan beramal salih. Oleh karena itu orang tua harus menanamkan akidah pada anak sejak dini.

Tabel 8.

Pola Asuh terhadap Anak

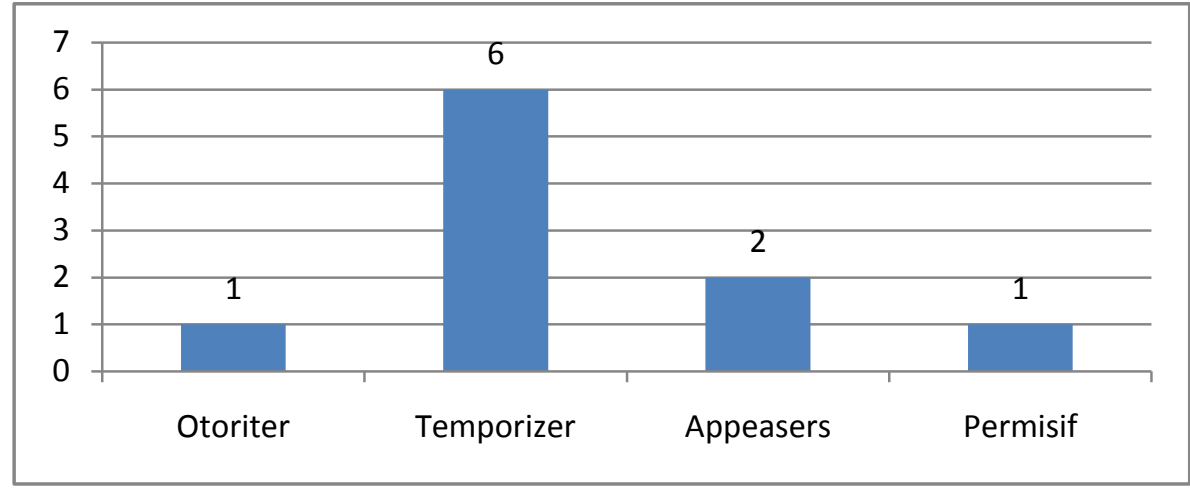

Berdasarkan gambaran tabel di atas pola asuh yang dilakukan orang tua muda adalah sebanyak 1 orang menerapkan gaya pola asuh otoriter, sebanyak 6 orang menerapkan pola asuh temporizer (pola asuh yang tidak konsisten), sebanyak 2 orang melakukan pola asuh appeasers (pola asuh khawatir) daan 1 orang menerapkan pola asuh permisif (bebas). Namun pada kenyataannya banyak dari subjek yang menitipkan anaknya ke orang tua mereka (neneknya).

f. Ekonomi dan Beban Pikiran

Pernikahan usia muda terjadi karena keadaan keluarga yang hidup digaris kemiskinan, untuk meringankan beban orang tuanya maka anak wanitanya dinikahkan dengan orang yang lebih mampu. Masalah ekonomi sangat penting dalam sebuah rumah tangga, karena ketika orang sudah menikah secara kewajiban mereka akan menanggung segala hal terkait kehidupan ke depan. Dengan usia yang masih belia, namun harus menanggung beban yang besar tentu mengakibatkan kondisi ekonomi subjek pernikahan dini termasuk memprihatinkan. 
"Untuk masalah ekonomi kami masih sulit. Untuk kebutuhan sehari-hari kami banyak dibantu oleh orang tua atau mertua. Kalau penghasilan setiap bulan tidak tentu, bahkan kadang tidak ada pemasukan sama sekali. Saya hanya ikut menangis ketika anak minta dibelikan sesuatu (mainan atau makanan kecil), sedangkan ketika mau membelikan saya tidak punya uang."

Berikut ini adalah tabel berdasarkan wawancara dengan subjek penelitian adalah sebagai berikut:

Tabel 9.

Pekerjaan Subjek Pernikahan Dini

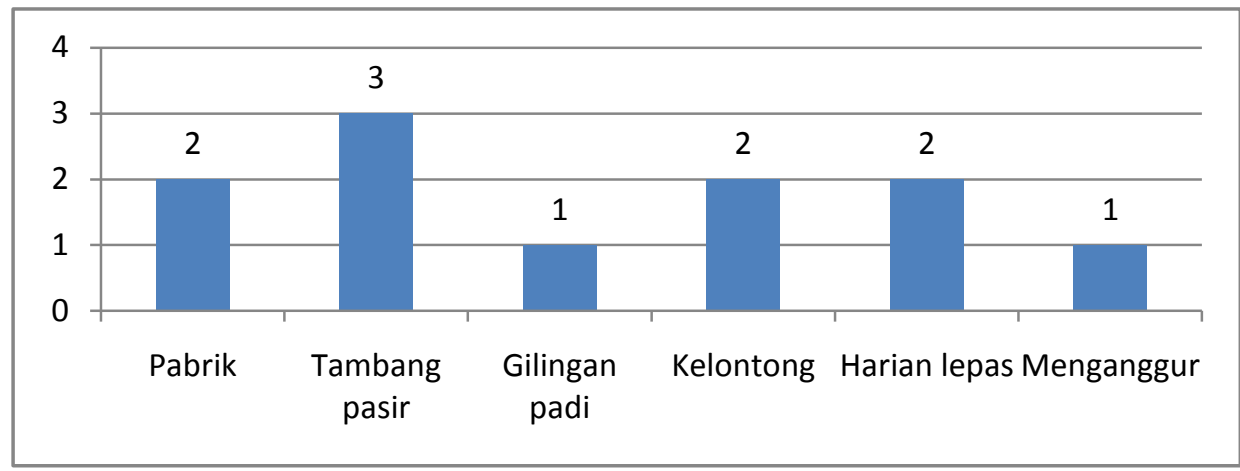

Berdasarkan tabel di atas dapat dijelaskan bahwa 2 orang bekerja di buruh pabrik, 2 orang bekerja buruh harian lepas dan 2 orang bekerja serabutan. Sebanyak 3 orang bekerja sebagai buruh tambang pasir, sedangkan 1 orang usaha gilingan padi, 2 orang usaha kelontong dan 1 orang masih menganggur. Bagi subjek yang menganggur semua kebutuhan masih dipenuhi oleh orang tua atau mertua.Dengan jenis pekerjaan di atas, maka untuk memenuhi kebutuhan sehari-hari menjadi kurang. Hal ini menambah depresi da kondisi rumah tangga mejadi kacau. Tekanan demi tekanan di alami oleh perlaku pernikahan dini. Hal ini sesuai dengan hasil interview dengan subjek, diantaranya hasilnya adalah:

"Untuk masalah ekonomi kami sangat susah pak. Jangankan untuk beli susu, untuk beli beras saja tidak mampu. Gaji suami tidak tentu. Sehingga kalau susu habis kalau tidak minta orang tua ya diberi uang mertua. Aku sangat sedih sekali. Kadang mikir bagaimana ke depannya hidup kami. Yang bisa aku lakukan hanya menangis menyesali apa yang telah dilakukan dulu."

Sedangkan berdasarkan interview dengan para subjek rata-rata penghasilan setiap bulan seperti tabel berikut ini: 
Tabel 10.

Penghasilan Rata-rata Subjek Pernikahan Dini

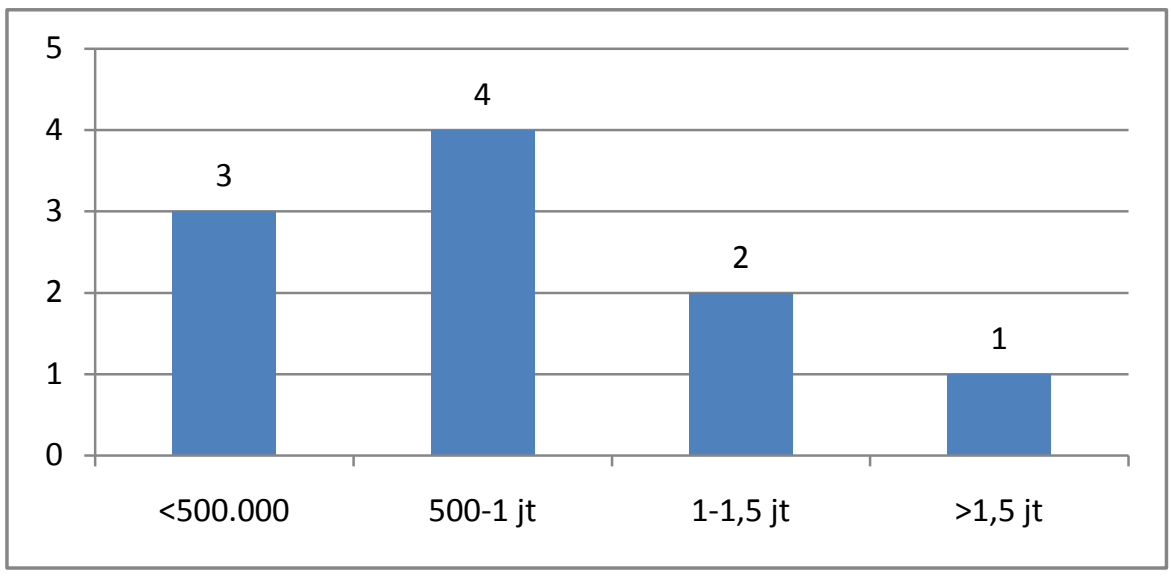

Berdasarkan tabel di atas, dapat dilihat sebanyak 3 orang rata-rata penghasilan di bawah Rp. 500.000, sedangkan 4 orang rata-rata penghasilan sebulan berkisar antara Rp. 500.000 sampai dengan 1.000.000, sebanyak 2 orang berkisar Rp. 1.000 .000 sampai 1.500.000 dan sebanyak 1 orang berpenghasilan di atas Rp. 1.500.000.

g. Pendidikan Terhenti

Dari sisi pendidikan subjek penelitian terhenti dari melanjutkan pendidikan. Ada beberapa subjek yang berkeinginan melanjutkan melalui kejar paket, namun karena waktu dan rata-rata masih merawat anak sehingga niatannya mereka belum terealisasi Berdasarkan wawancara dengan subjek, penyebaran pendidikannya adalah sebagai berikut:

Tabel 11.

Data Pendidikan Pernikahan Dini

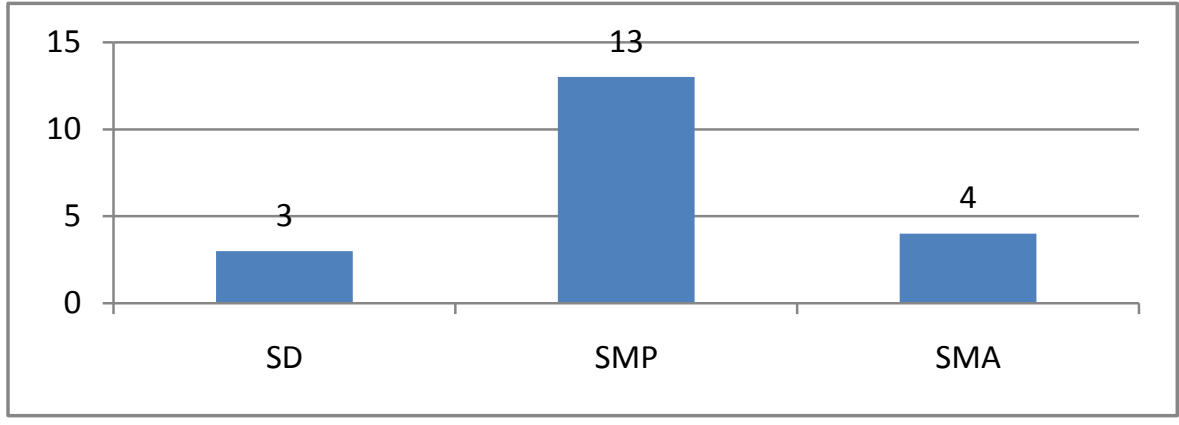

Berdasarkan tabel di atas dapat dilihat bahwa sebanyak 3 orang hanya lulus SD, sedangkan yang sempat mengenyam pendidikan SMP sebanyak 13 dan tingkat SMA sebanyak 4 orang. Peneliti kemudian mewawancarai salah satu subjek. Tentang keberlanjutan sekolah, kemudian dijawab: 
"Ya sedih lah, kecewa. Aku kaya nyesal gitu lho pak. Kan temen-temen masih sekolah kan jadi iri gitu hlo. Coba dulu saya tidak hanya nuruti nafsu, pasti aku masih sekolah seperti teman-temanku. Sedangkan saya mau lanjut sudah mikir anak. Tapi untuk mencari pekerjaan sekerang harus punya pendidikan minimal SMA.”

\section{STRATEGI MENGHADAPI DAMPAK NEGATIF PERNIKAHAN DINI}

Angka pernikahan di usia muda setiap tahun terus mengalami peningkatan sehingga diperlukan upaya untuk menekan tingginya angka pernikahan usia muda. Untuk itu diperlukan langkah yang konkret dari semua stakehorders baik dari masyarakat maupun pemerintah. Beberapa langkah yang dapat dilakukan antara lain:

1. Pembinaan oleh Keluarga dan Penyuluh Agama

Keluarga adalah tempat pertama kali anak belajar mengenal aturan yang berlaku di lingkungan keluarga dan masyarakat. Orang tua bertugas sebagai pengasuh, pembimbing, pemelihara, dan sebagai pendidik terhadap anak-anaknya. Orang tua adalah pihak yang sering kali bersinggungan dengan seorang anak dalam kehidupan sehari-hari.Keluarga dan penyuluh agama KUA Kecamatan Sanden telah melakukan kerjasama dengan baik guna mencegah munculnya dampak negatif pasca pernikahan dini. Ada beberapa tahapan yang telah dilakukan oleh keluarga dan penyuluh agama dalam mencegah terjadinya dampak negatif dari pernikahan dini, yaitu:

\section{a. Komunikasi}

Orang tua sudah berusaha membimbing, menasehati dan menunjukkan dampak negatif yang bisa terjadi pada pernikahan usia dini kepada anak-anak mereka bahwa pernikahan usia dini itu sangat rawan terjadi perceraian, tidak pandai merawat anak, sulit mencari perkerjaan. Komunikasi yang terjadi dalam keluarga ini diungkapkan ketika Peneliti berkunjung ke rumah bapak Wajirin, ayah dari Yunita Riyan Hidayah yang masih tinggal serumah.

"Nggih sampun kulo kandani pak anak kulo, yen nikah usia muda niku resikone gedhe, dereng siap cekel gawe kangge nyukupi butuh, dereng becus momong anak, gampang muntap sing ujung ujunge kosrek ing kluargo. Nggih kulo kandani kudu sabar nek onten masalah kluwargo, mboten sithik-sithik pegat". Sudah pernah saya nasehati pak anak saya, kalau menikah usia dini itu sangat 
beresiko, belum siap bekerja untuk memenuhi kebutuhan, belum pandai mengurus anak, mudah emosi yang berujung pertengkaran keluarga. Juga sudah saya nasehati untuk senantiasa sabar apabila ada persoalan keluarga jangan mudah mungucapkan kata cerai.

Pada kasus pasangan nikah usia dini yang lain, Sri Lestari ibu dari pasangan Joko Winarno dengan Aprilia Kartika Dewi juga senantiasa melakukan komunikasi dengan baik. Komunikasi yang terjadi dalam keluarga ini diungkapkan ketika Peneliti berkunjung ke rumah ibu Sri Lestari.

"Mas Joko sudah sering kami minta untuk bersabar menghadapi Tika, lebih banyak ngalah karena sudah lebih dewasa".

Penyuluh Agama Islam KUA Kecamatan Sanden juga telah melaksanakan perannya dengan baik pada persoalan ini, melalui program Bimbingan Caten yaitu bimbingan calon manten. Bimbingan caten ini diadakan sebagai salah satu bentuk pelayanan yang diberikan KUA kepada seluruh pasangan calon manten. Khusus pasangan caten usia dini penyuluh agama bekerja sama dengan penghulu KUA dalam hal menginformasikan data-data caten, kemudian penyuluh agama memberikan bimbingan secara khusus, dengan materi yang mendalam untuk pencegahan prefentif terhadap dampak yang lebih luas dari pernikahan pasangan usia dini tersebut. Bentuk lain yang dilaksanakan oleh Penyuluh Agama adalah melakukan kunjungan ke rumah pasangan nikah usia dini. Kunjungan ini dilakukan secara berkala untuk memantau perkembangan keluarganya, persoalan-persoalan yang muncul, dan solusi-solusi yang bisa ditempuh.

b. Motivasi

Motivasi orang tua terhadap anaknya yakni pasangan nikah usia dini sudah dilakukan, walaupun pada akhirnya orang tua hanya menyerahkan semua pada anaknya karena para orang tua menganggap anak mereka sudah bisa menentukan mana yang baik dan mana yang buruk bagi anak mereka. Keluarga juga sudah memotifasi untuk meneruskan jenjang pendidikan, hal ini diungkapkan ketika Peneliti berkunjung ke rumah bapak Wajirin, ayah dari Yunita Riyan Hidayah yang masih tinggal serumah. 
"Kulo nggih pun surung pak, nek purun nggih le sekolah diteruske minimal SMA, kulo ken pados nggen sinau paket C niko kajenge saget disambi.”. Sudah saya motifasi pak, kalau mau sekolahnya diteruskan minimal jenjang SMA, saya suruh mencari pendidikan kejar paket $\mathrm{C}$ agar bisa dilakukan sambil lalu.

Motivasi juga sudah diberikan orang tua kepada pasangan nikah usia dini dalam soal pekerjaan, bahkan bimbingan dan pendampingan juga dilakukan. Bimbingan dan pendampingan ini diungkapkan ketika Peneliti berkunjung ke rumah bapak Wajirin, ayah dari Yunita Riyan Hidayah yang masih tinggal serumah.

"Sing kakung nggih pun kulo arahke, rasah isen nyambut gawe. Sak gawean gaweane nggih pun kulo ajak ten pasar bantu kulo sadean wedus”. Yang lakilaki juga sudah saya bimbing, tidak usah merasa malu untuk memulai kerja. Pekerjaan seadanya juga sudah saya ajak ke Pasar membatu saya jualan kambing pak.

c. Pentauladanan

Orang tua telah memberikan pentauladaan kepada anak puteri mereka salah satunya dengan menceritakan kepada anak puteri mereka bahwa mereka dulu tidak dibolehkan oleh orang tua mereka menikah usia dini karena sudah banyak contohnya orang yang menikah usia dini itu sering mengalami perceraian. Sedangkan model pembinaan yang dilakukan oleh KUA Sanden kepada keluarga yang menikah karena usia dini dengan melakukan bimbingan atau pembinaan khusus.

2. Pemerintah Daerah (Desa dan KUA Sanden)

Dengan banyaknya pernikahan usia dini akan berpengaruh pada pendidikan mereka, yang ujung-ujungnya bagi anak usia dini belum mendapatkan pengalaman dan pengetahuan maupun skill yang cukup untuk mendapatkan pekerjaan. Pemerintah Kecamatan Sanden, Puskesmas, Desa dan KUA Sanden memang belum maksimal bekerja sama dalam membuat program, melakukan berbagai kegiatan untuk mengatasi dampak negatif pernikahan dini. Program dan kegiatan yang telah dilaksanakan yaitu: 
a. Tahap Dinasehati

Tahap awal yang dilakukan pemerintah di Kecamatan Sanden untuk menangani pernikahan dini dengan penasehatan. Penasehatan dilakukan oleh Pegawai Pencatat Pernikahan Nikah KUA Kecamatan Sanden atau oleh Penghulu pada saat ada masyarakat yang mendaftar pernikahan tetapi dari persyaratan terdapat umur yang tidak sesuai dengan Undang-undang perkawinan di Indonesia. Apabila, karena bukan alasan yang urgent sebaiknya rencana pernikahan diundur sampai usia kedua mempelai cukup. Namun bila karena kekhususan (perempuan hamil) maka pernikahan bisa dilakukan dengan syarat mendapat surat dispensasi dari pengadilan Agama Kabupaten Bantul.

b. Tahap Pendataan

Data kasus pernikahan dini yang terjadi di wilayah kecamatan Sanden sudah tercatat di KUA Kecamatan Sanden dengan baik, namun data ini baru sebatas kasus yang pelaksanaan pernikahan berada di wilayahh Sanden. Pendataan ini dilakukan pada pemerintahan kepala desa yang baru sehingga baru berjalan kurang lebih 1 tahun. Dari hasil pendataan tersebut pemerintah Desa di Kecamatan Sanden menemukan beberapa anak yang seharusnya masih usia sekolah tetapi memilih menikah dan ada pula penduduk yang menikah tetapi akad nikahnya di luar Kecamatan Sanden.

c. Tahap Sosialisasi

Kegiatan ini sebagai bentuk pencegahan preventif terjadinya kasus pernikahan dini agar tidak semakin meningkat jumlahnya. Mengatasi pernikahan dini di desa-desa dengan sosialisasi ke masyarakat dengan cara pada saat ada kegiatan kemasyarakatan misalnya peringatan maulid nabi, gotong royong, posyandu dan lain-lain, pada saat sambutan kepala desa dengan memberikan motivasi kepada orang tua untuk melanjutkan pendidikan ke yang lebih tinggi paling tidak sampai lulus SMA/MA dengan begitu anak-anak yang ingin melakukan pernikahan sudah mencukupi umur dan sesuai dengan undang-undang perkawinan sehingga tidak adanya pelanggaran terhadap undang-undang. Selain itu juga mensosialisasi efek negatif dari pernikahan dini kepada para siswa, baik terhadap masa depan pelaku maupun anak kedepannya. 
Selain itu pemerintah juga sering bekerja sama dengan sekolah SMA/SMK yang ada di Sanden dengan cara melakukan sosialisasi tentang bahaya pernikahan dini. Serta selalu menanamkan motivasi untuk belajar dengan rajin dan menghindari pergaulan yang bebas.

d. Perketat Undang-undang Pernikahan

Di Kecamatan Sanden sebenarnya untuk masyarakat sudah mulai takut melangsungkan pernikahan dini karena pada saat ini aturan-aturan mengenai pernikahan sudah diperketat oleh pemerintah daerah, pemerintah desa maupun Kantor Urusan Agama. Hal tersebut terjadi karena masyarakat tidak ingin menempuh prosedur yang sulit hingga harus ke pengadilan Kabupaten Bantul.

\section{KESIMPULAN}

Dari hasil kajian yang telah dilakukan oleh peneliti, maka penelitian ini menyimpulkan sebagai berikut:

1. Penyebab dari pernikahan dini di kecamatan Sanden kabupaten Bantul adalah karena hamil diluar nikah (MBA) dan kondisi orang tua yang meliputi faktor ekonomi, pendidikan, pola asuh dan tingkat pemahaman agama.

2. Dampak psikologi dari pernikahan dini adalah pendidikan dan ekonomi, hubungan sosial, penyesuaian diri, harmonisasi keluarga serta pola asuh anak dan perceraian

3. Startegi dari dampak negatif pernikahan dini adalah :

a. Pembinaan dan pendampingan oleh Keluarga dan penyuluh KUA dengan cara 1) berkomunikasi secara intens dengan anak, 2) selalu memberikan motivasi serta 3) memberikan tauladan yang positif terhadap anak.

b. Pemerintah (Desa dan Penyuluh KUA) dengan cara 1) memberikan nasehat atau penyuluhan tentang bahaya pergaulan dan penyuluhan tentang kesehatan reproduksi, 2) pendataan orang-orang yang akan menikah, 3) mengadakan sosialisasi ke Desa, sekolah-sekolah dengan menggandeng KUA dan Puskesmas, serta 4) memperketat undang-undang tentang pernikahan. 


\section{DAFTAR PUSTAKA}

Abu Ahmadi, Psikologi Sosial, Jakarta: Rineka Cipta, 2009.

Abu al-Ghifari, Pernikahan Dini Dilema Generasi Ekstrafagansa, Bandung: Rineka Cipta, 1998.

Agus Dariyo, Psikologi Perkembangan Dewasa Muda, Bandung: UPI, 1999.

Bimo Walgito, Bimbingan dan Konseling Perkawinan, Yogyakarta: Yayasan Penerbitan Fakultas Psikologi UGM, 2000.

Ida Bagus Gde Manuaba, Ilmu Kebidanan, Penyakit Kandungan dan KB, Jakarta: EGC, 1998

Lexy J. Moleong, Metodologi Penelitian Kualitatif, Bandung: Remaja Rosda karya, 2001.

Moch. Sochib. 2010, Pola Asuh Orang Tua dalam Membantu Anak Mengembangkan Disiplin Diri, Jakarta: Rineka Cipta, 2010.

Uber Silalahi, Metode Penelitian Sosial, Jakarta: Refika Aditama, 2010.

Uwaidah, Syaikh Kamil Muhammad, Fiqih Wanita, Jakarta: Pustaka al-Kautsar, 1998. 